\title{
Exogenous Amino Acids Stimulate Net Muscle Protein Synthesis in the Elderly
}

Elena Volpi, ${ }^{*}$ Arny A. Ferrando, ${ }^{*}$ Catherine W. Yeckel, ${ }^{\star}$ Kevin D. Tipton, ${ }^{\star}$ and Robert R. Wolfe ${ }^{\star \neq \S}$

$*$ Department of Surgery and ${ }^{\ddagger}$ Department of Anesthesiology, The University of Texas Medical Branch, Galveston, Texas 77550; and

${ }^{\S}$ Shriners Burns Institute, Galveston, Texas 77550

\begin{abstract}
We have investigated the response of amino acid transport and protein synthesis in healthy elderly individuals (age $71 \pm 2 \mathrm{yr}$ ) to the stimulatory effect of increased amino acid availability. Muscle protein synthesis and breakdown, and amino acid transport were measured in the postabsorptive state and during the intravenous infusion of an amino acid mixture. Muscle-free amino acid kinetics were calculated by means of a three compartment model using data obtained by femoral arterio-venous catheterization and muscle biopsies from the vastus lateralis during the infusion of stable isotope tracers of amino acids. In addition, muscle protein fractional synthetic rate (FSR) was measured. Peripheral amino acid infusion significantly increased amino acid delivery to the leg, amino acid transport, and muscle protein synthesis when measured either with the three compartment model $(P<0.05)$ or with the traditional precursorproduct approach (FSR increased from $0.0474 \pm 0.0054$ to $0.0940 \pm 0.0143 \% / \mathrm{h}, P<0.05)$. Because protein breakdown did not change during amino acid infusion, a positive net balance of amino acids across the muscle was achieved. We conclude that, although muscle mass is decreased in the elderly, muscle protein anabolism can nonetheless be stimulated by increased amino acid availability. We thus hypothesize that muscle mass could be better maintained with an increased intake of protein or amino acids. (J. Clin. Invest. 1998. 101:2000-2007.) Key words: aging • metabolism • transport $\bullet$ stable isotopes $\bullet$ tracers
\end{abstract}

\section{Introduction}

Total skeletal muscle mass declines with aging, and this muscle atrophy is accompanied by a reduction in muscle strength (1). The age-related changes in muscle mass and function lead to a reduction in performance, increased risk for falls, and increased vulnerability to injury, especially bone fracture. Furthermore, decrease in muscle function can lead to reduced physical activity, which may have possible metabolic effects including decreased bone density, obesity, and impaired glucose tolerance $(1,2)$.

The age-dependent reduction in muscle mass could be associated with an impairment in muscle protein metabolism, as

Address correspondence to Robert R. Wolfe, Metabolism Unit, Shriners Burns Institute, 815 Market Street, Galveston, TX 77550. Phone: 409-770-6605. FAX: 409-770-6825. E-mail: rwolfe@sbi.utmb.edu

Received for publication 16 June 1997 and accepted in revised form 19 February 1998.

J. Clin. Invest.

(C) The American Society for Clinical Investigation, Inc. 0021-9738/98/05/2000/08 \$2.00

Volume 101, Number 9, May 1998, 2000-2007

http://www.jci.org previous studies reported that muscle protein synthesis is slower in healthy elderly subjects than in young people (3-6). A recent study has ruled out the hypothesis that myofibrillar protein synthesis is impaired in elderly humans because of a reduction in the availability of specific mRNAs encoding actin and myosin (7). This suggests that the cause for the reduced muscle protein synthesis observed in the elderly is more likely to be attributed to alterations in posttranscriptional events. The most important factor in the translation of mRNA is likely to be the availability of amino acids.

Studies in animals (8) and in humans (9-11) have shown that amino acid availability is an essential factor in the regulation of muscle protein metabolism. A recent study performed in our laboratory showed that, in young subjects, hyperaminoacidemia stimulates net muscle protein synthesis by increasing amino acid transport into the muscle cells (12). These data lead to the conclusion that amino acid transport is a major determinant in the regulation of protein anabolism. The observation that the plasma amino acid concentration pattern in the elderly is different from the plasma amino acid composition of young humans (13) could be an indirect sign of an alteration in transport. Furthermore, in vitro studies reported that the aging process in isolated cells leads to a reduction in neutral amino acid transport (L system; 14) and intracellular neutral amino acid pools (15), that in turn may reduce the substrate availability for protein synthesis. Moreover, a study in rats showed that in vivo aging is associated with a complete loss of the response of amino acid transport system A to increased amino acid availability (16). Therefore, it is possible that the alterations of muscle protein metabolism in the elderly are due to an alteration of amino acid transport activity. The observation that a mixed meal stimulates myofibrillar protein synthesis to the same extent in the elderly as in the young (5) does not rule out this hypothesis, because no data on muscle protein breakdown and/or muscle protein net balance were provided. In fact, if amino acid transport was impaired in the elderly, the postprandial increase in protein synthesis would not lead to net protein deposition due to a concomitant increase in protein breakdown. If so, this would be analogous to the catabolic state after severe burn injury, in which a deficiency in inward amino acid transport is related to a net catabolism of muscle proteins, despite an increase in muscle protein synthesis, even in the fed state (17). A defect in amino acid transport and/or in the ability of muscle to switch from net catabolism to the net anabolic state in the elderly would be evident during increased amino acid availability (i.e., nutritional intake), when the entry of amino acids into the cells should increase as already demonstrated in the young (12). If there is a deficiency in transport in the elderly, an increase in blood amino acid concentration will not stimulate net muscle protein accretion, because the exogenously administered amino acids will not enter the cell.

We designed the present study to determine if increased amino acid availability increases amino acid transport into the muscle and stimulates the net incorporation of amino acids into muscle proteins in elderly individuals. Therefore, we mea- 
sured the kinetics of three essential and one nonessential amino acid in the leg muscles of normal elderly volunteers in the postabsorptive state and during the intravenous infusion of an amino acid mixture.

\section{Methods}

Subjects. The study was approved by the Institutional Review Board of the University of Texas Medical Branch, Galveston, TX. Six healthy elderly male volunteers (age $71 \pm 2 \mathrm{yr}$, mean \pm SEM) were recruited through the Center on Aging Volunteers Registry of the University of Texas Medical Branch. All subjects gave informed, written consent before participating in the study. The eligibility of the volunteers was assessed by performing a set of screening tests, which included a physical examination, electrocardiogram, pulmonary function tests, chest x-ray, blood count, plasma electrolytes, blood glucose concentration, liver, and renal function tests. Exclusion criteria were heart disease, hypo- or hyper-coagulation disorders, artery or vein diseases, hypertension, diabetes, obesity, cancer, chronic pulmonary diseases, infectious diseases, and allergy to iodides.

The subjects were active (i.e., living on their own with no limitation in ambulation or problems with falls) but untrained. Their body mass index (BMI) ${ }^{1}$ was $28 \pm 3 \mathrm{~kg} / \mathrm{m}^{2}$. Five subjects had leg muscle volume measured by means of magnetic resonance imaging (18) (image acquisition: GE Signa 1.5, General Electric, Milwaukee, WI; image processing: NIH-Image software, NIH public domain analysis package). One subject was unable to undergo the procedure due to claustrophobia. The measured total muscle volume of the studied leg was normalized by the squared height to obtain a "leg muscle stature index," which is conceptually similar to the BMI: the greater the leg muscle stature index, the larger the relative leg muscle size. We chose to express leg muscle volume by height rather than percent leg volume, because the latter depends not only on the muscle size but also on the adiposity of the subject, so that a lean sarcopenic subject would have a percent leg muscle much higher than an obese individual with normal muscle mass. The total muscle volume, as well as the leg muscle stature index of the elderly group $(n=5$, age $69 \pm 1 \mathrm{yr}$, weight $78.8 \pm 2 \mathrm{~kg}$, height $167 \pm 1 \mathrm{~cm}$, BMI $28 \pm 1 \mathrm{~kg} / \mathrm{m}^{2}$ ), was significantly lower than those of a BMI-matched group of young men $(n=5$, age $30 \pm 2 \mathrm{yr}$, weight $86.7 \pm 5.2 \mathrm{~kg}$, height $181 \pm 2 \mathrm{~cm}$, BMI $26 \pm 1 \mathrm{~kg} / \mathrm{m}^{2}$, leg muscle volume): total leg muscle volume $4.52 \pm 0.15$ versus $6.72 \pm$ $0.46 \mathrm{~L}, P<0.01$; leg muscle stature index $1.62 \pm 0.03$ versus $2.04 \pm 0.10$ $\mathrm{L} / \mathrm{m}^{2}, P<0.02$; elderly versus young, respectively.

Protocol. Each subject was studied on one occasion during the postabsorptive state. To avoid metabolic changes due to recent modifications of the diet, the volunteers were instructed to eat their usual diet during the week preceding the study. On the morning of the study, the subjects were admitted to the Clinical Research Center of the University of Texas Medical Branch at $0500 \mathrm{~h}$, after an overnight fast. At $0600 \mathrm{~h}$, polyethylene catheters were inserted into a left forearm vein for infusion of labeled amino acids, into a right wrist vein for arterialized blood sampling and into the left femoral artery and vein for blood sampling. The femoral arterial catheter was also used for the infusion of Indocianine green (ICG).

After obtaining a blood sample for the measurement of background amino acid enrichment and ICG concentration, a primed, continuous infusion of L-[ring ${ }^{2} \mathrm{H}_{5}$ ]phenylalanine was started, followed after $60 \mathrm{~min}$ by $\mathrm{L}-\left[2,3,3,4,5,5,5,6,6,6-{ }^{2} \mathrm{H}_{10}\right]$ leucine, $\mathrm{L}-\left[2-{ }^{15} \mathrm{~N}\right]$ lysine, and $\mathrm{L}-\left[1-{ }^{13} \mathrm{C}\right]$ alanine. Tracer infusion was maintained until the end of the experiment $(480 \mathrm{~min})$. The following isotope infusion rates (IR) and priming doses (PD) were used: $\mathrm{L}$ - $\left[\right.$ ring $\left.{ }^{2} \mathrm{H}_{5}\right]$ phenylalanine: $\mathrm{IR}=$ $0.05 \mu \mathrm{mol} \cdot \mathrm{kg}^{-1} \cdot \mathrm{min}^{-1}, \mathrm{PD}=2 \mu \mathrm{mol} / \mathrm{kg}$; L- $[2,3,3,4,5,5,5,6,6,6-$ ${ }^{2} \mathrm{H}_{10}$ ]leucine: $\mathrm{IR}=0.08 \mu \mathrm{mol} \cdot \mathrm{kg}^{-1} \cdot \mathrm{min}^{-1}, \mathrm{PD}=4.8 \mu \mathrm{mol} \cdot \mathrm{kg}^{-1}$;

1. Abbreviations used in this paper: $\mathrm{BMI}$, body mass index; FSR, fractional synthetic rate; GCMS, gas-chromatography mass-spectrometry; ICG, Indocianine green; IR, infusion rates; PD, priming doses.
L- $\left[2-{ }^{15} \mathrm{~N}\right]$ lysine: $\mathrm{IR}=0.08 \mu \mathrm{mol} \cdot \mathrm{kg}^{-1} \cdot \mathrm{min}^{-1}, \mathrm{PD}=7.2 \mu \mathrm{mol} \cdot \mathrm{kg}^{-1}$; $\mathrm{L}-\left[1{ }^{13} \mathrm{C}\right]$ alanine: $\mathrm{IR}=0.35 \mu \mathrm{mol} \cdot \mathrm{kg}^{-1} \cdot \mathrm{min}^{-1}, \mathrm{PD}=35 \mu \mathrm{mol} \cdot \mathrm{kg}^{-1}$. At $120 \mathrm{~min}$, the first muscle biopsy was taken from the lateral portion of the left vastus lateralis muscle, $\sim 20 \mathrm{~cm}$ above the knee, using a 4-mm Bergström biopsy needle (Depuy, Warsaw, IN). The tissue was immediately frozen in liquid nitrogen and stored at $-80^{\circ} \mathrm{C}$ until analysis.

To measure the leg blood flow, a continuous infusion of ICG dye $\left(0.5 \mathrm{mg} \cdot \mathrm{ml}^{-1}\right)$ was started into the femoral artery $\left(1 \mathrm{ml} \cdot \mathrm{min}^{-1}\right)$ at $230 \mathrm{~min}$ and maintained until $270 \mathrm{~min}$. Between 240 and $270 \mathrm{~min}$, four blood samples were taken every $10 \mathrm{~min}$ from the femoral and wrist veins to measure plasma ICG concentration. Between 240 and 300 min, four blood samples were taken, one every $20 \mathrm{~min}$, from the femoral artery and vein, to measure whole blood concentration and enrichment of free amino acids. To allow sampling from the femoral artery, the ICG infusion was briefly stopped and quickly resumed. At $300 \mathrm{~min}$, an additional blood sample was drawn to measure insulin concentration and a second muscle biopsy was taken.

After the basal period (0-300 min), a primed, continuous infusion of unlabeled amino acids was started into the left forearm vein and was maintained for $3 \mathrm{~h}$ until the end of the study. A commercial amino acid mixture (10\% Travasol, total amino acids $100 \mathrm{mg} / \mathrm{ml}$; Clintec Nutrition Co., Deerfield, IL) and a freshly prepared glutamine solution (30 $\mathrm{mg} \cdot \mathrm{ml}^{-1}$; Kyowa, Tokyo, Japan) were separately infused at the rate of $1.35 \mathrm{ml} \cdot \mathrm{kg}^{-1} \cdot \mathrm{h}^{-1}$ (prime $0.45 \mathrm{ml} \cdot \mathrm{kg}^{-1}$ ) and $0.45 \mathrm{ml} \cdot \mathrm{kg}^{-1} \cdot \mathrm{h}^{-1}$ (prime $0.15 \mathrm{ml} \cdot \mathrm{kg}^{-1}$ ), respectively. The concentrations of the amino acids in the amino acid mixture (Travasol) were the following $\left[\mathrm{mg} \cdot \mathrm{ml}^{-1}\right.$ and $\left(\mu \mathrm{mol} \cdot \mathrm{l}^{-1}\right)$, respectively]: alanine 20.7 (232.3), arginine 11.5 (66.0), glycine 10.3 (137.2), histidine 4.8 (30.9), isoleucine 6.0 (45.7), leucine 7.3 (55.6), lysine 5.8 (39.7), methionine 4 (26.8), phenylalanine 5.6 (33.9), proline 6.8 (59.1), serine 5.0 (47.6), threonine 4.2 (35.3), tryptophan 1.8 (8.8), tyrosine 0.4 (2.2), and valine 5.8 (49.5). The total amino acid infusion was $148.5 \mathrm{mg} \cdot \mathrm{kg}^{-1} \cdot \mathrm{h}^{-1}$. Between 420 and $480 \mathrm{~min}$, the measurement of leg blood flow was repeated and blood samples were taken, as described for the basal period. At $480 \mathrm{~min}$, before stopping the tracer and amino acid infusion, the third muscle biopsy was taken.

Analytical methods. The blood samples for the measurement of amino acid concentration and enrichment were collected as previously described (19). An internal standard solution was added to the blood samples $\left(100 \mu \mathrm{l} \cdot \mathrm{ml}^{-1}\right.$ of blood) for the measurement of blood amino acid concentrations. This solution contained $50 \mu \mathrm{mol} \cdot 1$ of L-[ring- ${ }^{13} \mathrm{C}_{6}$ ]phenylalanine, $122 \mu \mathrm{mol} \cdot 1^{-1}$ of L-[5,5,5- $\left.{ }^{2} \mathrm{H}_{3}\right]$ leucine, $180 \mu \mathrm{mol} \cdot \mathrm{l}^{-1}$ of $\mathrm{L}-\left[1,2-{ }^{13} \mathrm{C}_{2}, 6,6-{ }^{2} \mathrm{H}_{2}\right]$ lysine, and $329 \mu \mathrm{mol} \cdot \mathrm{l}^{-1}$ of $\mathrm{L}-\left[2,3,3,3-{ }^{2} \mathrm{H}_{4}\right]$ alanine. Blood amino acids were separated using cation exchange chromatography (20). The enrichments and the concentrations of phenylalanine, leucine, lysine, and alanine in arterial and venous blood samples were determined on the propyl ester/heptafluorobutyryl derivatives of the amino acids (21) using gas-chromatography mass-spectrometry (GCMS) in positive chemical ionization (GC HP 5890, MSD HP 5989; Hewlett Packard, Palo Alto, CA), and monitoring the ions 404, 409, 410 for phenylalanine; 370, 373, 380 for leucine; 581, 582, 585 for lysine; and 328, 329, 332 for alanine.

Muscle samples were weighed and the proteins were precipitated with $450 \mu \mathrm{l}$ of $14 \%$ perchloric acid. An internal standard solution (2 $\mu \mathrm{l} / \mathrm{mg}$ of muscle tissue) was added to measure the intracellular concentrations of phenylalanine, leucine, lysine, and alanine. The solution contained $3 \mu \mathrm{mol} \cdot 1^{-1}$ of L-[ring- ${ }^{13} \mathrm{C}_{6}$ ]phenylalanine, $6 \mu \mathrm{mol} \cdot \mathrm{1}^{-1}$ of L-[5,5,5-2 $\left.\mathrm{H}_{3}\right]$ leucine, $5 \mu \mathrm{mol} \cdot 1^{-1}$ of L- $\left[1,2-{ }^{13} \mathrm{C}_{2}, 6,6-{ }^{2} \mathrm{H}_{2}\right]$ lysine, and $85 \mu \mathrm{mol} \cdot \mathrm{l}^{-1}$ of $\mathrm{L}-\left[2,3,3,3-{ }^{2} \mathrm{H}_{4}\right]$ alanine. The tissue was homogenized, centrifuged, and the supernatant was collected. This procedure was repeated three times. The enrichment and concentrations of the intracellular amino acids were determined on their t-BDMS derivatives (20) by GCMS in electron impact mode, monitoring the ions 234, 239, 240 for phenylalanine; 302, 305, 312 for leucine; 431, 432, 435 for lysine; and 260,261, 264 for alanine. The pellet was washed and dried. The proteins were hydrolyzed in $\mathrm{HCl} 6 \mathrm{~N}$ at $110^{\circ} \mathrm{C}$ for $24 \mathrm{~h}$. The hydrolysate was processed as blood samples and phenylalanine enrich- 


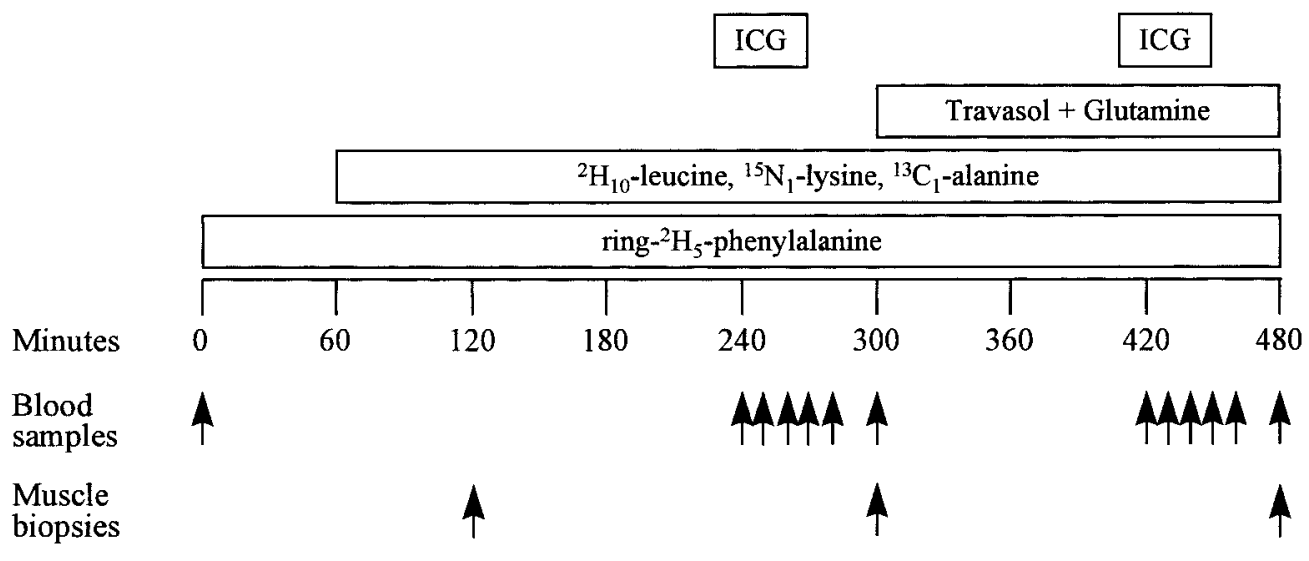

Figure 1. Study design. Six normal elderly volunteers were studied on one occasion. The study was divided in a basal postabsorptive period $(0-300 \mathrm{~min})$ and an amino acid infusion period (300-480 min). After background blood samples were taken (0 $\mathrm{min})$ a primed, continuous infusion of ring- ${ }^{2} \mathrm{H}_{5}$-phenylalanine was started, followed after $1 \mathrm{~h}(60 \mathrm{~min})$ by a primed, continuous infusion of ${ }^{2} \mathrm{H}_{10}$-leucine, ${ }^{15} \mathrm{~N}_{1}$-lysine, and ${ }^{13} \mathrm{C}_{1}$-alanine (see text for priming doses and infusion rates). From 300 min to the end of the study (480

min) a primed, continuous infusion amino acid mixture (Travasol) plus freshly prepared glutamine was administered (see text for priming doses and infusion rates). Between 240-300 min and 420-480 min, blood samples were taken every $20 \mathrm{~min}$ from the femoral artery and vein to measure muscle protein kinetics. Muscle biopsies were taken at 120, 300, and $480 \mathrm{~min}$. To measure leg blood flow, from 230-270 min and from 410-450 min a continuous infusion of ICG was administered through the femoral artery catheter and blood samples were taken from a wrist vein and from the femoral vein every $10 \mathrm{~min}$ from $240-270 \mathrm{~min}$ and from $420-450 \mathrm{~min}$.

ment was measured by GCMS (GC 8000 series, MD 800; Fisons Instruments, Manchester, UK), using chemical ionization and the standard curve approach (22).

The concentration of plasma insulin was measured with a commercial radio immunoassay kit (Incstar, Stillwater, MN). The serum concentration of ICG was measured by means of a spectrophotometer at $\lambda=805 \mathrm{~nm}$.

Calculations. This protocol was designed to simultaneously assess, in skeletal muscle, the kinetics of intracellular free amino acids and the fractional synthetic rate (FSR) of muscle proteins by the incorporation of labeled phenylalanine.

The kinetics of intracellular amino acids were described by a three compartment model recently developed in our laboratory (23; Fig. 2). The model enables the calculation of the rate of amino acid delivery to the leg $\left(F_{\text {in }}\right)$, the rate at which amino acids leave the leg $\left(\mathrm{F}_{\text {out }}\right)$, the rate of inward $\left(\mathrm{F}_{\mathrm{M}, \mathrm{A}}\right)$ and outward $\left(\mathrm{F}_{\mathrm{V}, \mathrm{M}}\right)$ muscle transmembrane transport, the rate of intracellular appearance $\left(\mathrm{F}_{\mathrm{M}, 0}\right)$ of the amino acids (from protein breakdown for phenylalanine, leucine, and lysine, from protein breakdown, and de novo synthesis for alanine), the rate of amino acid use $\left(\mathrm{F}_{0, \mathrm{M}}\right)$ for protein synthesis for phenylalanine and lysine, that are not oxidized into the muscle, and for protein synthesis plus oxidation for leucine. The simultaneous infusion of four different amino acid tracers enabled us to quantify the activity of the major amino acid transport systems. Phenylalanine and leucine are the preferential substrates of the $\mathrm{L}$ system, alanine may be transported by the A, ASC, and L systems, and lysine is transported by the $\mathrm{y}^{+}$system (24). Thus, because the four amino acid tracers we infused are transported and metabolized differently, we have been able to evaluate and quantify, simultaneously and separately, the transmembrane transport and intracellular events of amino acid metabolism, distinguishing the fate of each amino acid.

The three compartment model parameters (Fig. 2) were calculated as follows:

$$
\begin{aligned}
& F_{\text {in }}=C_{\mathrm{A}} \cdot B F \\
& F_{\text {out }}=C_{\mathrm{V}} \cdot B F \\
& N B=\left(C_{\mathrm{A}}-C_{\mathrm{V}}\right) \cdot B F \\
& F_{\mathrm{M}, \mathrm{A}}=\left[\left(\frac{E_{\mathrm{M}}-E_{\mathrm{V}}}{E_{\mathrm{A}}-E_{\mathrm{M}}} \cdot C_{\mathrm{V}}\right)+C_{\mathrm{A}}\right] \cdot B F
\end{aligned}
$$

$$
\begin{aligned}
& F_{\mathrm{V}, \mathrm{M}}=\left[\left(\frac{E_{\mathrm{M}}-E_{\mathrm{V}}}{E_{\mathrm{A}}-E_{\mathrm{M}}} \cdot C_{\mathrm{V}}\right)+C_{\mathrm{V}}\right] \cdot B F \\
& F_{\mathrm{V}, \mathrm{A}}=F_{\mathrm{in}}-F_{\mathrm{M}, \mathrm{A}} \\
& F_{\mathrm{M}, \mathrm{O}}=F_{\mathrm{M}, \mathrm{A}} \cdot\left(\frac{E_{\mathrm{A}}}{E_{\mathrm{M}}}-1\right) \\
& F_{\mathrm{O}, \mathrm{M}}=F_{\mathrm{M}, \mathrm{O}}+N B
\end{aligned}
$$

where $\mathrm{C}_{\mathrm{A}}$ and $\mathrm{C}_{\mathrm{V}}$ are the blood-free amino acid concentrations in the femoral artery and vein, respectively; $\mathrm{E}_{\mathrm{A}}, \mathrm{E}_{\mathrm{V}}$, and $\mathrm{E}_{\mathrm{M}}$ are amino acid enrichments, expressed as tracer/tracee ratio, in the femoral artery and vein blood, and in muscle, respectively; BF is leg blood flow. Data are expressed per $100 \mathrm{ml}$ of leg volume (23).

Using phenylalanine and lysine data, we were able to calculate protein synthesis efficiency, defined as the fraction of the intracellular amino acid rate of appearance that is incorporated into the muscle proteins, as these two amino acids are not oxidized in the muscle and, therefore, the $\mathrm{F}_{0, \mathrm{M}}$ represents the amount of amino acid incorporated in the muscle proteins:

Protein synthesis efficiency $=\frac{F_{\mathrm{O}, \mathrm{M}}}{F_{\mathrm{M}, \mathrm{A}}+F_{\mathrm{M}, \mathrm{O}}}$.

Leg plasma flow was calculated from the steady-state dye concentration values in the femoral and wrist vein, as previously described $(25,26)$. Leg blood flow was calculated by correcting the plasma flow by the hematocrit.

Additionally, we determined the FSR of muscle proteins by measuring the incorporation rate of the isotopes into the proteins and using the precursor-product model (27). Muscle FSR was calculated by dividing the increment in enrichment in the product $\left(\Delta \mathrm{E}_{\mathrm{P}}\right)$, that is, the increment in protein-bound phenylalanine tracer/tracee ratio, by the enrichment in the precursor (free intracellular phenylalanine tracer/ tracee ratio), in the basal period (2nd-1st biopsy $\Delta \mathrm{E}_{\mathrm{P}}$ ) and during amino acid infusion (3rd-2nd biopsy $\Delta \mathrm{E}_{\mathrm{P}}$ ):

$$
F S R=\frac{\Delta E_{\mathrm{P}}}{t} \cdot \frac{1}{\frac{E_{\mathrm{M}(1)}+E_{\mathrm{M}(2)}}{2}} \cdot 60 \cdot 100
$$

where $\mathrm{E}_{\mathrm{M}(1)}$ and $\mathrm{E}_{\mathrm{M}(2)}$ are the phenylalanine enrichments, expressed as tracer/tracee ratio, in the free muscle pool in the two subsequent 


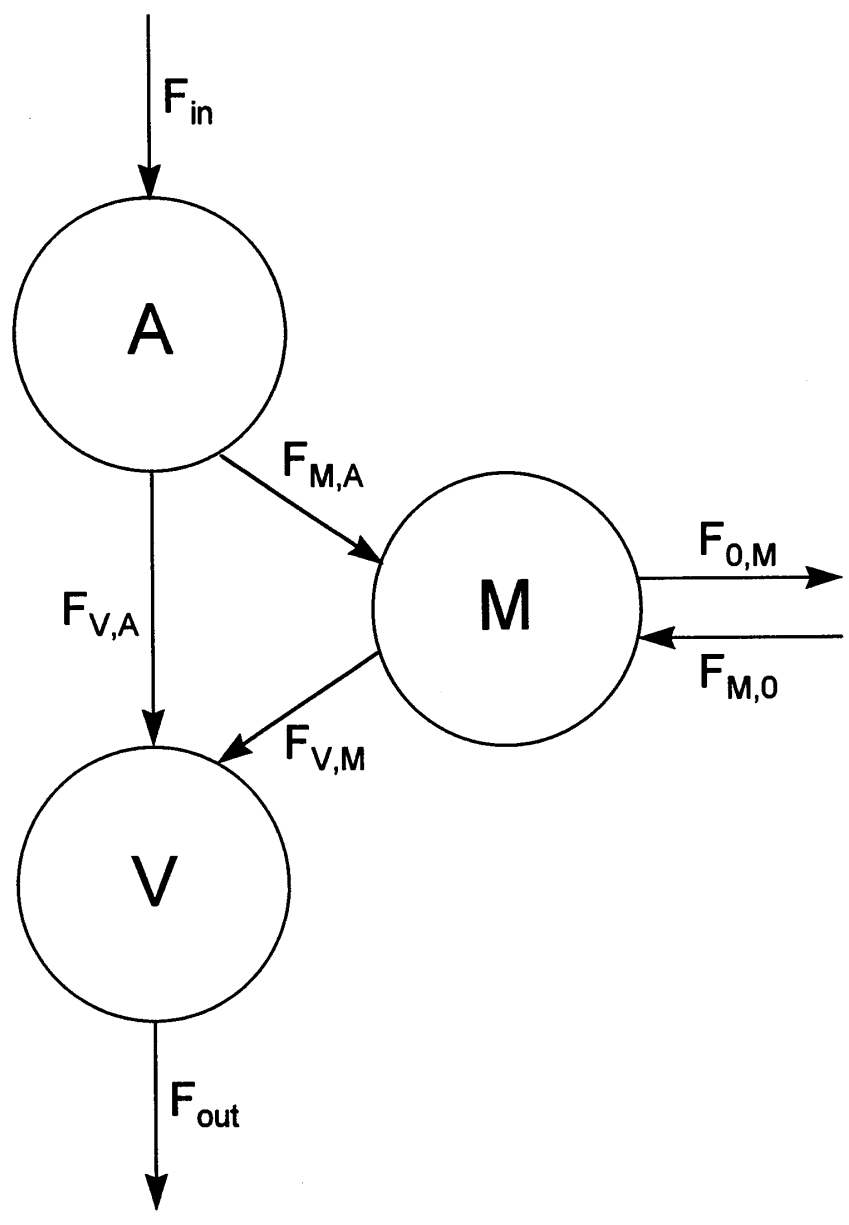

Figure 2. Three compartment model of leg amino acid kinetics. Free amino acid pools in femoral artery $(A)$, femoral vein $(V)$, and muscle $(M)$ are connected by arrows indicating unidirectional amino acid flow between the compartments. Amino acids enter the leg via femoral artery $\left(\mathrm{F}_{\text {in }}\right)$ and leave the leg via femoral vein $\left(\mathrm{F}_{\text {out }}\right)$. $\mathrm{F}_{\mathrm{V}, \mathrm{A}}$ is the direct flow from artery to vein of the amino acids that do not enter the intracellular fluid. $\mathrm{F}_{\mathrm{M}, \mathrm{A}}$ and $\mathrm{F}_{\mathrm{V}, \mathrm{M}}$ are the inward and the outward transport from the artery to the muscle and from the muscle to the vein, respectively. $\mathrm{F}_{\mathrm{M}, 0}$ is the intracellular amino acid appearance from proteolysis for phenylalanine, leucine, and lysine, or proteolysis plus de novo synthesis for alanine. $\mathrm{F}_{0, \mathrm{M}}$ is the rate of disappearance of intracellular amino acids for protein synthesis (phenylalanine and lysine) and protein synthesis plus other metabolic fates, if any, for alanine and leucine. biopsies, and $t$ is the time interval between the two sequential biopsies. The results are expressed in $\% \cdot \mathrm{h}^{-1}$, multiplying by the factors $60\left(\mathrm{~min} \cdot \mathrm{h}^{-1}\right)$ and 100 .

Statistical analysis. The comparisons between the basal period and the intravenous infusion of amino acids within the elderly group were carried out for each variable using the two-tailed paired $t$ test. The comparisons between elderly and young subjects were carried out using the two-tailed unpaired $t$ test for equal or unequal variances, according to the results of the test for equality of variances. Differences were considered significant at $P<0.05$. The linear relationships between variables were measured with the Pearson correlation coefficient.
Table I. Effect of Amino Acid (AA) Infusion on the Concentrations of Free Amino Acids in the Femoral Artery and Vein, and in the Muscle Cells

\begin{tabular}{lccc}
\hline & Artery & Vein & Muscle \\
\hline & & $\mu m o l / l i t e r$ & \\
Phenylalanine & & & \\
$\quad$ Basal & $93 \pm 4$ & $105 \pm 5$ & $191 \pm 21$ \\
AA infusion & $243 \pm 13^{*}$ & $229 \pm 15^{*}$ & $426 \pm 51^{*}$ \\
Leucine & & & \\
Basal & $142 \pm 10$ & $152 \pm 10$ & $199 \pm 36$ \\
AA infusion & $352 \pm 18^{*}$ & $327 \pm 19^{*}$ & $393 \pm 43^{*}$ \\
Lysine & & & \\
Basal & $259 \pm 20$ & $272 \pm 22$ & $775 \pm 162$ \\
AA infusion & $427 \pm 39^{*}$ & $411 \pm 41^{*}$ & $844 \pm 176^{\ddagger}$ \\
Alanine & & & \\
Basal & $420 \pm 31$ & $521 \pm 26$ & $2241 \pm 311$ \\
AA infusion & $1007 \pm 61^{*}$ & $1055 \pm 76^{*}$ & $3315 \pm 292^{\ddagger}$ \\
& & & \\
\hline
\end{tabular}

Data are mean \pm SEM. $* P<0.01$ versus basal, ${ }^{\ddagger} P<0.05$ versus basal.

\section{Results}

In the last hour of the basal (240-300 $\mathrm{min}$ ) and amino acid infusion (420-480 min) periods, blood amino acid concentrations and enrichments in the femoral artery and vein were at steady state.

The average concentrations of free amino acids in the femoral artery and vein, and the muscle cells increased significantly during amino acid infusion (Table I).

Exogenous amino acid infusion significantly decreased the enrichments of the four traced amino acids (Table II) in the femoral artery and vein. Intracellular amino acid enrichments decreased during amino acid infusion as well. The ratio between intracellular and arterial enrichment increased significantly for all amino acids except lysine.

Insulin concentrations increased during amino acid infusion $\left(6.2 \pm 2.5\right.$ versus $10.2 \pm 3.6 \mu \mathrm{U} \cdot \mathrm{ml}^{-1}$, basal versus amino acid infusion, $P<0.05)$.

Blood flow was unaffected by amino acid infusion (6.08 \pm 1.66 versus $6.44 \pm 1.66 \mathrm{ml} \cdot \mathrm{min}^{-1} \cdot 100 \mathrm{ml} \mathrm{leg}{ }^{-1}$, basal versus amino acid infusion), thus, we used the mean value of each subject to calculate the model-derived parameters.

During amino acid infusion, the increment $\Delta \mathrm{E}_{\mathrm{P}}$ of the enrichment of muscle protein-bound phenylalanine was not different from that observed in the basal state $\left(3.34 \cdot 10^{-5} \pm 0.29\right.$. $10^{-5}$ versus $4.51 \cdot 10^{-5} \pm 0.76 \cdot 10^{-5}$, basal versus amino acid infusion). Because the amino acid infusion decreased the intracellular free phenylalanine enrichment, the net result was a significant increase in the FSR of muscle proteins during amino acid infusion when compared to the basal state (FSR: $0.0474 \pm 0.0054$ versus $\left.0.0940 \pm 0.0143 \% \cdot \mathrm{h}^{-1}, P<0.05\right)$ (Fig. 3).

The model-derived parameters of leg muscle free amino acid kinetics in the six elderly volunteers in the basal period (240-300 $\mathrm{min}$ ) and during the infusion of an amino acid mixture (AA infusion, 420-480 min reported in Table III). Amino acid infusion significantly increased the delivery of the four traced amino acids to the leg $\left(\mathrm{F}_{\mathrm{in}}\right)$ and their escape from the leg $\left(\mathrm{F}_{\text {out }}\right)$. However, amino acid infusion caused a shift in the 
Table II. Effect of Amino Acid (AA) Infusion on the Enrichments of Free Amino Acids in the Femoral Artery and Vein, and in the Muscle Cells

\begin{tabular}{|c|c|c|c|c|}
\hline & \multicolumn{3}{|c|}{ Tracer to Tracee Ratio } & \multirow[b]{2}{*}{ Muscle/Artery } \\
\hline & Artery & Vein & Muscle & \\
\hline \multicolumn{5}{|l|}{ Phenylalanine } \\
\hline Basal & $0.072 \pm 0.001$ & $0.055 \pm 0.001$ & $0.043 \pm 0.002$ & $0.60 \pm 0.02$ \\
\hline AA infusion & $0.034 \pm 0.001 *$ & $0.031 \pm 0.001 *$ & $0.029 \pm 0.001 *$ & $0.85 \pm 0.03^{*}$ \\
\hline \multicolumn{5}{|l|}{ Leucine } \\
\hline Basal & $0.046 \pm 0.002$ & $0.034 \pm 0.002$ & $0.026 \pm 0.001$ & $0.56 \pm 0.04$ \\
\hline AA infusion & $0.026 \pm 0.001 *$ & $0.023 \pm 0.001 *$ & $0.021 \pm 0.001^{\ddagger}$ & $0.80 \pm 0.04 *$ \\
\hline \multicolumn{5}{|l|}{ Lysine } \\
\hline Basal & $0.071 \pm 0.005$ & $0.053 \pm 0.003$ & $0.028 \pm 0.002$ & $0.41 \pm 0.05$ \\
\hline AA infusion & $0.047 \pm 0.005^{*}$ & $0.035 \pm 0.003 *$ & $0.019 \pm 0.003 *$ & $0.41 \pm 0.06$ \\
\hline \multicolumn{5}{|l|}{ Alanine } \\
\hline Basal & $0.061 \pm 0.004$ & $0.033 \pm 0.002$ & $0.020 \pm 0.001$ & $0.34 \pm 0.02$ \\
\hline AA infusion & $0.029 \pm 0.001 *$ & $0.022 \pm 0.001 *$ & $0.016 \pm 0.001^{\ddagger}$ & $0.57 \pm 0.03^{*}$ \\
\hline
\end{tabular}

Data are mean \pm SEM. $* P<0.01$ versus basal, ${ }^{\ddagger} P<0.02$ versus basal.

net balance from net output to net uptake, which was significant for all the traced amino acids except lysine. Amino acid infusion also significantly increased the inward transport rates $\left(\mathrm{F}_{\mathrm{M}, \mathrm{A}}\right)$ of phenylalanine and leucine, with no significant effect on the outward transport rates $\left(\mathrm{F}_{\mathrm{V}, \mathrm{M}}\right)$. Alanine and lysine inward transport rates increased during amino acid infusion but the responses did not reach statistical significance. However, the inward transport rates $\left(\mathrm{F}_{\mathrm{M}, \mathrm{A}}\right)$ of the four traced amino acids were significantly and positively correlated with their respective rates of delivery $\left(\mathrm{F}_{\text {in }}\right)$ (phenylalanine $r=0.9497$, leucine $r=0.8377$, lysine $r=0.8434$, alanine $r=0.9124$; $P<$

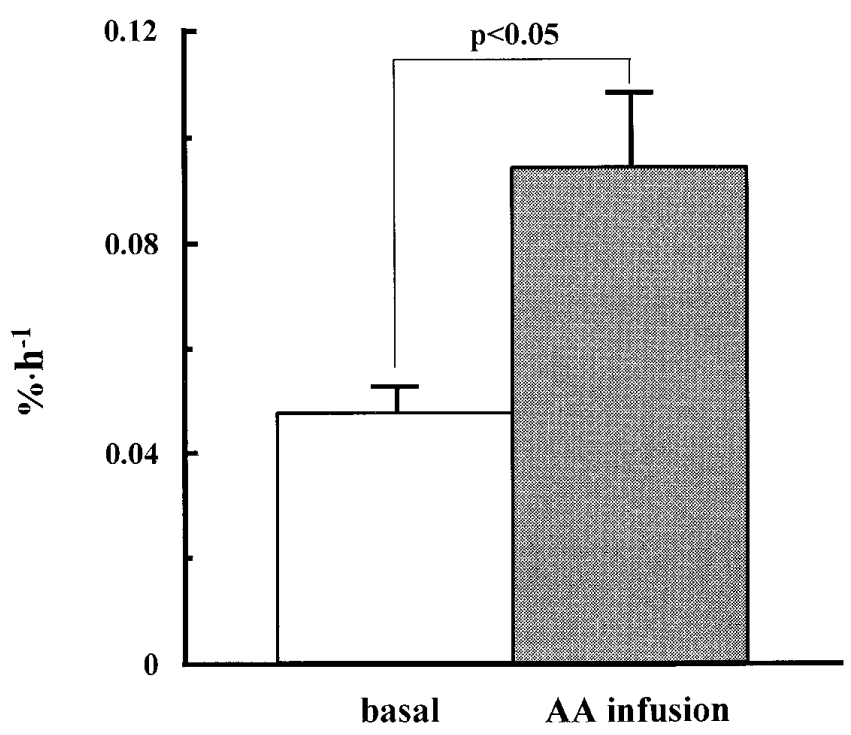

Figure 3. Muscle protein fractional synthetic rate in one group of healthy elderly subjects during the postabsorptive state (basal, open bar) and the intravenous infusion of an amino acid mixture ( $A A$ infusion, gray bar). The intravenous infusion of amino acids increased the synthesis rate of muscle proteins by $\sim 100 \%(P<0.05)$.
0.001) and arterial concentrations $\left(\mathrm{C}_{\mathrm{A}}\right)$ (phenylalanine $r=$ 0.7046 , leucine $r=0.5677$, lysine $r=0.5788$, alanine $r=$ 0.6773; $P<0.05$ ), indicating a strong relationship between amino acid transport into the muscle cells and arterial amino acid availability. The intracellular rates of appearance $\left(\mathrm{F}_{\mathrm{M}, 0}\right)$, an index of proteolysis when measured with phenylalanine, leucine, and lysine, and of proteolysis plus de novo synthesis when measured with alanine, did not change during amino acid infusion. Consistent with the direct incorporation data, the rate of intracellular utilization of phenylalanine for protein synthesis increased significantly during amino acid infusion. Also, the leucine utilization rate increased, whereas the values for lysine and alanine, although increased, did not reach statistical significance. The utilization rates $\left(\mathrm{F}_{0, \mathrm{M}}\right)$ of the four traced amino acids were significantly $(P<0.01)$ and positively related to their respective rate of delivery into the cell $\left(\mathrm{F}_{\mathrm{M}, \mathrm{A}}\right)$ (phenylalanine $r=0.7750$, leucine $r=0.7442$, lysine $r=$ 0.7230 , alanine $r=0.8916$ ), indicating that the intracellular utilization of amino acids increases when their availability increases. On the other hand, no relationship was found between the amino acid utilization rates and their intracellular concentrations.

Protein synthesis efficiency did not change from the basal values during amino acid infusion for either phenylalanine ( $27 \pm 2$ versus $23 \pm 4 \%, P=\mathrm{NS}$, basal versus amino acid infusion) and lysine $(54 \pm 5$ versus $63 \pm 6 \%, P=\mathrm{NS}$, basal versus amino acid infusion).

\section{Discussion}

This study demonstrates that amino acids alone can stimulate muscle protein anabolism in elderly individuals whose muscle mass was reduced, as compared to their younger counterparts. Increasing the amino acid delivery to the leg by the intravenous infusion of an amino acid mixture apparently increased net muscle protein synthesis by increasing inward amino acid transport. This is supported by the fact that protein synthesis efficiency did not change during amino acid infusion, indicating that in the elderly the increase in net protein synthesis was 
Table III. Effect of Intravenous Amino Acid (AA) Infusion on the Parameters of Leg Muscle Free Amino Acid Kinetics in the Elderly

\begin{tabular}{|c|c|c|c|c|c|c|c|c|c|}
\hline & $\mathrm{F}_{\text {in }}$ & $\mathrm{F}_{\text {out }}$ & NB & $\mathrm{F}_{\mathrm{M}, \mathrm{A}}$ & $\mathrm{F}_{\mathrm{V}, \mathrm{M}}$ & $\mathrm{F}_{\mathrm{V}, \mathrm{A}}$ & $\mathrm{F}_{\mathrm{M}, 0}$ & $\mathrm{~F}_{0, \mathrm{M}}$ & $\mathrm{F}_{\mathrm{M}, \mathrm{A}} / \mathrm{F}_{\text {in }}$ \\
\hline \multicolumn{10}{|c|}{$\mathrm{nmol} \cdot \mathrm{min}^{-1} \cdot 100 \mathrm{ml} \mathrm{leg}-1$} \\
\hline \multicolumn{10}{|l|}{ Phenylalanine } \\
\hline Basal & $585 \pm 127$ & $666 \pm 150$ & $-81 \pm 24$ & $314 \pm 74$ & $394 \pm 97$ & $272 \pm 70$ & $217 \pm 52$ & $136 \pm 28$ & $0.55 \pm 0.05$ \\
\hline AA infusion & $1557 \pm 357 *$ & $1463 \pm 335^{*}$ & $+94 \pm 45^{\ddagger}$ & $1056 \pm 323^{\ddagger}$ & $962 \pm 306$ & $502 \pm 128$ & $141 \pm 28$ & 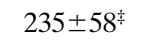 & $0.64 \pm 0.09$ \\
\hline \multicolumn{10}{|l|}{ Leucine } \\
\hline Basal & $880 \pm 186$ & $945 \pm 197$ & $-65 \pm 16$ & $543 \pm 135$ & $608 \pm 148$ & $337 \pm 102$ & $383 \pm 89$ & $318 \pm 79$ & $0.59 \pm 0.08$ \\
\hline AA infusion & $2227 \pm 478^{*}$ & $2059 \pm 437 *$ & $+168 \pm 55^{\ddagger}$ & $1643 \pm 525^{\ddagger}$ & $1475 \pm 501$ & $584 \pm 351$ & $349 \pm 91$ & $517 \pm 119$ & $0.70 \pm 0.13$ \\
\hline \multicolumn{10}{|l|}{ Lysine } \\
\hline Basal & $1651 \pm 386$ & $1731 \pm 403$ & $-80 \pm 29$ & $546 \pm 122$ & $626 \pm 149$ & $1105 \pm 306$ & $849 \pm 212$ & $769 \pm 191$ & $0.36 \pm 0.05$ \\
\hline AA infusion & $2795 \pm 691^{\ddagger}$ & $2652 \pm 651^{\ddagger}$ & $+142 \pm 102$ & $1065 \pm 275$ & $922 \pm 195$ & $1730 \pm 489$ & $1609 \pm 380$ & $1751 \pm 443$ & $0.43 \pm 0.07$ \\
\hline \multicolumn{10}{|l|}{ Alanine } \\
\hline Basal & $2588 \pm 513$ & $3280 \pm 709$ & $-692 \pm 244$ & $1469 \pm 254$ & $2161 \pm 455$ & $1119 \pm 265$ & $3098 \pm 710$ & $2406 \pm 590$ & $0.59 \pm 0.03$ \\
\hline AA infusion & $6673 \pm 1732^{\ddagger}$ & $7058 \pm 1899 \ddagger$ & $-386 \pm 204^{\ddagger}$ & $3837 \pm 1408$ & $4222 \pm 1603$ & $2836 \pm 794^{\ddagger}$ & $3494 \pm 1501$ & $3108 \pm 1314$ & $0.54 \pm 0.07$ \\
\hline
\end{tabular}

$\mathrm{F}_{\text {in }}$, amino acid flow into the leg from the systemic circulation via femoral artery. $\mathrm{F}_{\text {out }}$, amino acid flow from the leg to the systemic circulation via femoral vein. $\mathrm{NB}$, amino acid net balance across the leg; negative numbers indicate net release, positive numbers net uptake. $\mathrm{F}_{\mathrm{M}, \mathrm{A}}$, inward amino acid transport from the femoral artery into the free intracellular amino acid pool. $\mathrm{F}_{\mathrm{V}, \mathrm{M}}$, outward amino acid transport from the intracellular free amino acid pool to the femoral vein. $\mathrm{F}_{\mathrm{V}, \mathrm{A}}$, amino acid shunt from the artery to the vein without entering in the intracellular fluid. $\mathrm{F}_{\mathrm{M}, 0}$, intracellular amino acid appearance from proteolysis for phenylalanine, leucine, and lysine, from proteolysis and de novo synthesis for alanine. $\mathrm{F}_{0, \mathrm{M}}$, intracellular amino acid use for protein synthesis for phenylalanine and lysine, for protein synthesis, and other fates for leucine and alanine. $\mathrm{F}_{\mathrm{M}, \mathrm{A}} / \mathrm{F}_{\mathrm{in}}$, fraction of amino acids delivered to the leg that are taken up by the transport systems. Data are mean \pm SEM. $* P<0.01$ versus basal, ${ }^{\ddagger} P<0.05$ versus basal.

only due to the increase in intracellular amino acid availability. This peculiar effect of amino acids on muscle protein synthesis is similar to that previously observed in young individuals in similar experimental conditions (12). On the other hand, it contrasts with the effect of insulin (19) and testosterone (28) of which administration in young subjects caused an increase in protein synthesis in the absence of a concomitant increase in intracellular amino acid availability, thus, resulting in an enhancement of protein synthesis efficiency.

The inward amino acid transport rates $\left(\mathrm{F}_{\mathrm{M}, \mathrm{A}}\right)$ of the individual amino acids increased with the increase in amino acid delivery to the leg, as demonstrated by the significant linear correlation between the delivery rate to the leg (either $F_{\text {in }}$ or arterial concentration $\mathrm{C}_{\mathrm{A}}$ ) and the inward transport observed for each amino acid. This supports the notion that the transport of phenylalanine and leucine (L system), alanine (A, ASC, and L systems) and lysine ( $\mathrm{y}^{+}$system) (24) are all stimulated by increased amino acid availability. The increase in amino acid inward transport was also indirectly confirmed by the increase in the intracellular concentrations of amino acids, and the reduction in the difference between the intracellular and the arterial free amino acid enrichments (increase in the muscle/artery enrichment ratio, which reflects the percent of the intracellular pool derived from plasma). This finding suggests that, unlike in old rats (16) and in aging cultured cells (14), amino acid transport into the muscle cells in elderly healthy humans can be effectively stimulated by increased amino acid availability. Whereas in a general sense all transporters responded positively to the increased amino acid availability, the response of the different transporters was not the same. The systems affecting phenylalanine, leucine, and alanine transported into the muscle cells $\sim 60 \%$ of the delivered amino acids, as indicated by the ratio of inward transport to amino acid availability $\left(\mathrm{F}_{\mathrm{M}, \mathrm{A}} / \mathrm{F}_{\text {in }}\right)$. On the other hand, the $\mathrm{y}^{+}$ system responsible for lysine transport (24) behaved differently, because only $\sim 40 \%$ of the available amino acid was transported by this system. This probably explains the absence of a significant increase in the lysine $\mathrm{F}_{\mathrm{M}, \mathrm{A}}$ and muscle/artery enrichment ratio despite an increase in arterial concentration during amino acid infusion.

The increased amino acid delivery to the cells stimulated muscle protein synthesis in the elderly volunteers. The use of phenylalanine for protein synthesis increased significantly as calculated by the three compartment model $\left(\mathrm{F}_{0, \mathrm{M}} \sim+70 \%\right)$ or by the precursor-product approach (FSR $\sim+100 \%$ ). Because the breakdown rate $\left(\mathrm{F}_{\mathrm{M}, 0}\right)$ did not change, the overall effect was net protein deposition. This was reflected by a positive net balance of phenylalanine, providing further evidence for the stimulatory effect of amino acids on net protein synthesis. The lack of a significant effect of amino acid administration on lysine utilization rate $\left(\mathrm{F}_{0, \mathrm{M}}\right)$ could be explained by the large size of the free intracellular pool of this amino acid, which might prevent the detection of relatively small kinetic changes.

We found that the utilization rates $\left(\mathrm{F}_{0, \mathrm{M}}\right)$ of all the traced amino acids were significantly correlated with the respective rates of entry into the cells $\left(\mathrm{F}_{\mathrm{M}, \mathrm{A}}\right)$, so that the higher the amino acid delivery into the cells, the greater the utilization of amino acids. Theoretically, an increase in amino acid transport might increase amino acid use by simply providing more substrate to be used for protein synthesis (and oxidation when taking place in the muscle). However, consistent with recent data obtained in young subjects (12), we did not find any relation between the intracellular amino acid concentrations and their utilization rates. Therefore, the inward amino acid transport and amino acid use for protein synthesis seem to be related by factors other than the intracellular substrate concentration. In 
vitro data indicate that cell swelling due to amino acid-induced alterations in ion fluxes could be responsible for the increase in protein synthesis observed in hepatocytes during increased amino acid availability (29), but the relevance of this observation to the in vivo situation in muscle cells is unclear. Although the precise mechanism linking transport to synthesis remains to be determined, our data provide strong evidence for the beneficial effect of increased amino acid availability on muscle protein anabolism in the elderly, where the increase in amino acid delivery stimulates muscle protein deposition by increasing amino acid transport.

Previous studies in young humans have shown that blood flow increases during amino acid infusion $(12,30,31)$ and, thus, it could be partly responsible for the increase in amino acid delivery to the peripheral tissues and the consequent increase of amino acid transport and utilization rates (12). In the present study, we did not observe any significant difference in the blood flow rate during amino acid infusion. This could be the result of an age-related impairment in the responsiveness to the vasodilatory action of amino acids, similar to the agerelated impairment of the vascular response to insulin infusion (32). The absence of a response of blood flow to amino acids could have been responsible for a reduction of the positive effect of amino acid infusion on muscle protein metabolism, but our results indicate that this was a minor issue as muscle protein anabolism primarily relies on the blood amino acid concentrations via transport activity.

This was the first time we have used the three-pool model to describe muscle-free amino acid kinetics (23) in elderly subjects. The concordance of the results concerning protein synthesis and amino acid transport obtained both with this model and with model-independent parameters, such as FSR and $\mathrm{E}_{\mathrm{M}} /$ $\mathrm{E}_{\mathrm{A}}$, indicates that the three-pool model is also valid in elderly subjects.

Thus, in elderly people, although the total muscle mass and the myofibrillar (3-5) and mitochondrial fractional synthetic rates (6) are reduced, when compared to that of young individuals, the response of muscle amino acid transport and net protein synthesis to increased amino acid availability is preserved. In fact, not only the direction, but also the magnitude of the response of muscle amino acid transport and protein synthesis in this group of active elderly individuals were not different from that obtained in a group of young untrained subjects given the same amount of amino acids during a similar protocol (12; Table IV). The data on the table are presented as percent change from basal to account for difference in leg volume. In the elderly, as well as in the young, amino acid administration increased amino acid transport and muscle protein synthesis in the absence of any changes in the rates of protein breakdown, resulting in muscle net protein deposition as indicated by the shift of leg net balance from negative to positive in both groups. Furthermore, because protein synthesis efficiency was similar in the two age groups $(\sim 20-25 \%$ with phenylalanine and $\sim 55-60 \%$ with lysine) and remained unchanged during amino acid infusion, we can conclude that exogenous amino acids stimulate muscle protein anabolism only by increasing the availability of substrate for protein synthesis in the elderly as well as in the young. In addition, these results rule out any significant role for the slight increase in insulin concentrations with amino acid infusion observed both in the elderly and in the young (12), as protein synthesis efficiency increases with insulin (19). Our results are consistent with data obtained in
Table IV. Response of Amino Acid Transport and Use to the Intravenous Infusion of an Amino Acid Mixture in a Group of Elderly (Present Study) and in a Group of Young Subjects (from Reference 12)

\begin{tabular}{ccc}
\hline Young (12) & Plderly \\
\hline$\%$ change over basal values
\end{tabular}

\begin{tabular}{cccc} 
Phenylalanine & & & \\
$\mathrm{F}_{\mathrm{M}, \mathrm{A}}$ & $282 \pm 57$ & $222 \pm 60$ & 0.48 \\
$\mathrm{~F}_{0, \mathrm{M}}$ & $141 \pm 38$ & $73 \pm 19$ & 0.13 \\
Leucine & & & \\
$\mathrm{F}_{\mathrm{M}, \mathrm{A}}$ & $148 \pm 48$ & $197 \pm 43$ & 0.46 \\
$\mathrm{~F}_{0, \mathrm{M}}$ & $250 \pm 86$ & $69 \pm 32$ & 0.09 \\
Lysine & & & \\
$\mathrm{F}_{\mathrm{M}, \mathrm{A}}$ & $77 \pm 27$ & $122 \pm 57$ & 0.48 \\
$\mathrm{~F}_{0, \mathrm{M}}$ & $47 \pm 14$ & $267 \pm 166$ & 0.24 \\
Alanine & & & \\
$\mathrm{F}_{\mathrm{M}, \mathrm{A}}$ & $240 \pm 39$ & $141 \pm 61$ & 0.20 \\
$\mathrm{~F}_{0, \mathrm{M}}$ & $90 \pm 26$ & $34 \pm 57$ & 0.38 \\
$\mathrm{FSR}$ & $56 \pm 13$ & $120 \pm 59$ & 0.30 \\
& & & \\
\hline
\end{tabular}

Data are presented as delta increase from basal values to account for differences in leg volume. The delta increase from the basal values of the rates of amino acid transport $\left(\mathrm{F}_{\mathrm{M}, \mathrm{A}}\right)$, use $\left(\mathrm{F}_{0, \mathrm{M}}\right)$ for protein synthesis (phenylalanine and lysine) or for protein synthesis and other fates (leucine and alanine), and of the muscle protein FSR, were not different in the two age groups during the intravenous infusion of the same amount of amino acids. In both groups the rate of protein breakdown remained unchanged during the amino acid infusion; therefore, the leg net balance shifted from negative to positive (data not shown). Data are mean \pm SEM.

old rats, showing that the increase of muscle protein synthesis during amino acid infusion is preserved with age (33). This contrasts to the acutely catabolic response to stress in individuals of any age, where the increase of protein synthesis is accompanied by a greater increase of breakdown and an impairment of amino acid transport, thus resulting in net muscle loss (17). Our results support the notion that if there is a dietary basis (34-36) to the loss of muscle mass with aging, the lack of amino acid $(37,38)$ and energy intake $(39,40)$ is more likely the problem than is the inability to efficiently use amino acids once ingested. In fact, a positive balance of amino acids across muscle tissue was achieved during the infusion of amino acids, reflecting an anabolic response. The preservation of an anabolic response of muscle to amino acids allows us to hypothesize that muscle mass could be better maintained if adequate protein or amino acids were ingested.

\section{Acknowledgments}

We thank Marilyn Brodwick and James S. Goodwin (Sealy Center on Aging, The University of Texas Medical Branch of Galveston, Galveston, TX) for their assistance in recruiting the volunteers for the study.

This study was supported by the Shriners Hospitals grant No. 8490 and by a grant from the Sealy Center on Aging of the University of Texas Medical Branch. It was conducted at the General Clinical Research Center at the University of Texas Medical Branch at Galveston, TX, funded by the grant No. M0IRR00073 from the National Center for Research Resources, National Institutes of Health, United States Public Health Service. E. Volpi is the recipient of a fel- 
lowship from the Sealy Center on Aging of the University of Texas Medical Branch at Galveston.

\section{References}

1. Evans, W.J. 1995. What is sarcopenia? J. Gerontol. (Series A, Biological) 50A:5-8.

2. Dutta, C., and E.C. Hadley. 1995. The significance of sarcopenia in old age. J. Gerontol. (Series A, Biological) 50A:1-4.

3. Welle, S., C. Thornton, R. Jozefowicz, and M. Statt. 1993. Myofibrillar protein synthesis in young and old men. Am. J. Physiol. 264:E693.

4. Yarasheski, K.E., J.J. Zachwieja, and D.M. Bier. 1993. Acute effects of resistance exercise on muscle protein synthesis rate in young and elderly men and women. Am. J. Physiol. 265:E210-E214.

5. Welle, S., C. Thornton, M. Statt, and B. McHenry. 1994. Postprandial myofibrillar and whole body protein synthesis in young and old human subjects. Am. J. Physiol. 267:E599-E604.

6. Rooyackers, O.E., D.B. Adey, P.A. Ades, and K.S. Nair. 1996. Effect of age on in vivo rates of mitochondrial protein synthesis in human skeletal muscle. Proc. Natl. Acad. Sci. USA. 93:15364-15369.

7. Welle, S., K. Bhatt, and C. Thornton. 1996. Polyadenylated RNA, actin mRNA, and myosin heavy chain mRNA in young and old human skeletal muscle. Am. J. Physiol. 270:E224-E229.

8. Watt, P.W., M.E. Corbett, and M.J. Rennie. 1992. Stimulation of protein synthesis in pig skeletal muscle by infusion of amino acids during constant insulin availability. Am. J. Physiol. 263:E453-E460.

9. Bennet, W.M., A.A. Connacher, C.M. Scrimgeour, K. Smith, and M.J. Rennie. 1989. Increase in anterior tibialis muscle protein synthesis in healthy man during mixed amino acid infusion: studies of incorporation of $\left[1-{ }^{13} \mathrm{C}\right] \mathrm{leu}-$ cine. Clin. Sci. (Lond.). 76:447-454.

10. Fryburg, D.A., L.A. Jahn, S.A. Hill, D.M. Oliveras, and E.J. Barrett. 1995. Insulin and insulin-like growth factor-I enhance human skeletal muscle protein anabolism during hyperaminoacidemia by different mechanisms. $J$. Clin. Invest. 96:1722-1729.

11. Bennet, W.M., A.A. Connacher, C.M. Scrimgeour, and M.J. Rennie. 1990. The effect of amino acid infusion on leg protein turnover assessed by $\mathrm{L}-\left[{ }^{15} \mathrm{~N}\right]$ phenylalanine and L- $\left[1-{ }^{13} \mathrm{C}\right]$ leucine exchange. Eur. J. Clin. Invest. 20:4150

12. Biolo, G., K.D. Tipton, S. Klein, and R.R. Wolfe. 1997. An abundant supply of amino acids enhances the metabolic effect of exercise on muscle protein. Am. J. Physiol. 273:E122-E129.

13. Rudman, D., D.E. Mattson, A.G. Feller, R. Cotter, and R.C. Johnson. 1989. Fasting plasma amino acids in elderly men. Am. J. Clin. Nutr. 49:559-566.

14. Newton, R.B., J.L. Sullivan, and A.G. Debusk. 1984. Neutral amino acid transport and in vitro aging. Mech. Ageing Dev. 27:63-72.

15. Sambuy, Y., and A.H. Bittles. 1982. The effects of in vitro ageing on the composition of the intracellular free amino acid pool of human diploid fibroblasts. Mech. Ageing Dev. 20:279-287.

16. Leoni, S., S. Spagnuolo, L. Dini, M. Massimi, and L. Conti Devirgiliis. 1988. Regulation of amino acid transport in hepatocytes isolated from adult and old rats. Mech. Ageing Dev. 46:19-27.

17. Sakurai, Y., A. Aarsland, D.N. Herndon, D.L. Chinkes, E. Pierre, T.T. Nguyen, B.W. Patterson, and R.R. Wolfe. 1995. Stimulation of muscle protein synthesis by long-term insulin infusion in severely burned patients. Ann. Surg. 222:283-297.

18. Ferrando, A.A., C.A. Stuart, D.G. Brunner, and G.R. Hillman. 1995. Magnetic resonance imaging quantitation of changes in muscle volume during 7 days of strict bed rest. Aviat. Space Environ. Med. 66:976-981.

19. Biolo, G., R.Y. Declan Fleming, and R.R. Wolfe. 1995. Physiologic hy- perinsulinemia stimulates protein synthesis and enhances transport of selected amino acids in human skeletal muscle. J. Clin. Invest. 95:811-819.

20. Wolfe, R.R. 1992. Radioactive and stable isotope tracers in biomedicine. In Principle and Practice of Kinetic Analysis. Wiley-Liss, New York. 417-438.

21. Knapp, D.R. 1979. Amino acids and peptides. In Handbook of Analytical Derivatization Reactions. John Wiley \& Sons, Inc. New York. 242-337.

22. Calder, A.G., S.E. Anderson, I. Grant, M.A. McNurlan, and P.J. Garlick. 1992. The determination of low $\mathrm{d}_{5}$-phenylalanine enrichment $(0.002-0.09$ atom percent excess), after conversion to phenylethylamine, in relation to protein turnover studies by gas chromatography/electron ionization mass spectrometry. Rapid Commun. Mass Spectrom. 6:421-424.

23. Biolo, G., R.Y. Fleming, S.P. Maggi, and R.R. Wolfe. 1995. Transmembrane transport and intracellular kinetics of amino acids in human skeletal muscle. Am. J. Physiol. 268:E75-E84.

24. Guidotti, G.G., and G.C. Gazzola. 1992. Amino acid transporters: systematic approach and principles of controls. In Mammalian Amino Acid Transport. M.S. Kilberg and D. Haüssinger, editors. Plenum, New York. 3-29.

25. Jorfeldt, L., and J. Wahren. 1971. Leg blood flow during exercise in man. Clin. Sci. 41:459-473.

26. Jorfeldt, L., and A. Juhlin-Dannfelt. 1978. The influence of ethanol on splanchnic and skeletal muscle metabolism in man. Metabolism. 27:97-106.

27. Chinkes, D.L., J. Rosenblatt, and R.R. Wolfe. 1993. Assessment of the mathematical issues involved in measuring the fractional synthesis rate of protein using the flooding dose technique. Clin. Sci. 84:177-183.

28. Ferrando, A.A., K.D. Tipton, D.J. Doyle, S.M. Phillips, J. Cortiella, and R.R. Wolfe. 1997. Net protein synthesis and amino acid uptake with testosterone injection. FASEB (Fed. Am. Soc. Exp. Biol.) J. 11:A437. (Abstr.)

29. Rivas, T., E. Urcelay, C. Gonzalez-Manchon, R. Parrilla, and M.S. Ayuso. 1995. Role of amino acid-induced changes in ion fluxes in the regulation of hepatic protein synthesis. J. Cell Physiol. 163:277-284.

30. Lundholm, K., K. Bennegard, H. Zachrisson, F. Lundgren, E. Eden, and A.C. Moller-Loswick. 1987. Transport kinetics of amino acids across the resting human leg. J. Clin. Invest. 80:763-771.

31. Brundin, T., and J. Wahren. 1994. Effects of i.v. amino acids on human splanchnic and whole body oxygen consumption, blood flow, and blood temperatures. Am. J. Physiol. 266:E396-E402.

32. Meneilly, G.S., T. Elliot, M. Bryer-Ash, and J.S. Floras. 1995. Insulinmediated increase in blood flow is impaired in the elderly. J. Clin. Endocrinol. Metab. 80:1899-1903.

33. Mosoni, L., M.L. Houlier, P.P. Mirand, G. Bayle, and J. Grizard. 1993. Effect of amino acids alone or with insulin on muscle and liver protein synthesis in adult and old rats. Am. J. Physiol. 264:E614-E620.

34. Morgan, D.B., H.M. Newton, C.J. Schorah, M.A. Jewitt, M.R. Hancock, and R.P. Hullin. 1986. Abnormal indices of nutrition in the elderly: a study of different clinical groups. Age Ageing. 15:65-76.

35. Fiatarone, M.A., and W.J. Evans. 1993. The etiology and reversibility of muscle dysfunction in the aged. J. Gerontol. 48 (Spec No.):77-83.

36. Blaum, C.S., B.E. Fries, and M.A. Fiatarone. 1995. Factors associated with low body mass index and weight loss in nursing home residents. J. Gerontol. (Series A, Biological) 3:M162-M168.

37. Campbell, W.W., M.C. Crim, G.E. Dallal, V.R. Young, and W.J. Evans. 1994. Increased protein requirements in elderly people: new data and retrospective reassessments. Am. J. Clin. Nutr. 60:501-509.

38. Campbell, W.W., and W.J. Evans. 1996. Protein requirements of elderly people. Eur. J. Clin. Nutr. 50 (Suppl. 1):S180-S185.

39. Roberts, S.B., P. Fuss, M.B. Heyman, and V.R. Young. 1995. Influence of age on energy requirements. Am. J. Clin. Nutr. 62:1053S-1058S.

40. Reilly, J.J., A. Lord, V.W. Bunker, A.M. Prentice, W.A. Coward, A.J. Thomas, and R.S. Briggs. 1993. Energy balance in healthy elderly women. Brit. J. Nutr. 69:21-27. 